Prosiding Seminar Nasional Teknologi Informasi dan Kedirgantaraan : Transformasi Teknologi untuk Mendukung Ketahanan Nasional, Yogyakarta, 13 Desember 2018

SENATIK 2018, Vol. IV, ISBN 978-602-52742-0-6

DOI: http://dx.doi.org/10.28989/senatik.v4i0.243

\title{
THE BLUEPRINT OF AWOS IMPLEMENTATION FOR AVIATION SERVICES AT BMKG \\ Duati Wardani $^{1)}$, Selo Sulistyo ${ }^{2)}$, I Wayan Mustika ${ }^{3)}$
}

Departemen Teknik Elektro dan Teknologi Informasi, Universitas Gadjah Mada

J1. Grafika 2, Kampus UGM, Yogyakarta, 55281

Email : ${ }^{1}$ duati.wardani@mail.ugm.ac.id

\section{Abstract}

Weather is very critical for aviation. Especially regarding safety in air transportation. Badan Meteorologi, Klimatologi, dan Geofisika (BMKG) in its duties and functions provides aviation weather information, conducts the latest weather observation activities for the needs of takeoff and landing at airports. The World Meteorological Organization (WMO) has targeted automation with a target achievement in 2017. But currently in conducting the latest weather observations, BMKG still uses conventional weather observation systems even though at some airports Automated Weather Observing Systems (AWOS) have been installed. The automated weather observing system is still not fully implemented yet. This study aims to create a blueprint for the implementation of automatic weather observations for aviation services within the BMKG. Guidelines for making blueprint use the Enterprise Architecture Planning (EAP) framework. EAP defines business and architectural needs related to data, applications, and technology needed to implement automation. The final results achieved are in the form of a blueprint for the implementation of automated weather observing system for aviation services within the BMKG which can be a guide for BMKG in achieving the vision related to aviation weather services.

Keyword: BMKG, EAP, AWOS, aviation weather services

Abstrak

Cuaca merupakan hal yang sangat penting bagi dunia penerbangan. Apalagi menyangkut keselamatan dalam transportasi udara. Badan Meteorologi, Klimatologi, dan Geofisika (BMKG) dalam tugas dan fungsinya memberikan informasi cuaca penerbangan, melakukan kegiatan pengamatan cuaca terkini untuk keperluan tinggal landas dan pendaratan di bandara. World Meteorological Organization (WMO) telah menargetkan otomatisasi dengan target capaian di tahun 2017. Namun saat ini dalam melakukan pengamatan cuaca terkini, BMKG masih menggunakan sistem pengamatan cuaca konvensional meskipun di beberapa bandara telah dipasang sistem pengamatan cuaca otomatis (AWOS). Sistem pengamatan cuaca otommatis juga masih belum dilaksanakan dengan penuh. Penelitian ini bertujuan untuk membuat cetak biru (blueprint) implementasi pengamatan cuaca otomatis untuk pelayanan penerbangan di lingkungan BMKG. Panduan dalam pembuatan cetak biru menggunakan kerangka Enterprise Architecture Planning (EAP). EAP mendefinisikan kebutuhan bisnis dan arsitektur terkait data, aplikasi, dan teknologi yang dibutuhkan untuk mengimplementasikan otomatisasi. Hasil akhir yang dicapai adalah berupa blueprint implementasi pengamatan cuaca otomatis untuk pelayanan penerbangan di lingkungan BMKG yang dapat menjadi panduan bagi BMKG dalam mencapai visi terkait pelayanan cuaca penerbangan.

Kata Kunci : BMKG, EAP, AWOS, pelayanan cuaca penerbangan 


\section{Pendahuluan}

Perubahan cuaca sering berdampak pada kehidupan manusia, tak terkecuali dalam dunia penerbangan yang memegang prinsip menjaga keselamatan transportasi udara. Kecelakaan dalam penerbangan umumnya diakibatkan oleh 3 faktor utama yaitu: faktor teknis, faktor kesalahan manusia (human error), dan faktor cuaca [1]. Pelayanan informasi cuaca penerbangan yang cepat, tepat, akurat, dan terus menerus sangat diperlukan di setiap bandar udara, terutama di bandara yang memiliki frekuensi penerbangan yang padat dan sering mengalami perubahan cuaca yang cepat. Setiap pengguna informasi meteorologi untuk penerbangan wajib menggunakan informasi yang bersumber dari Unit Pelayanan Informasi Meteorologi [2]. Dalam melaksanakan tugas dan fungsinya, unit pelayanan informasi meteorologi/ stasiun meteorologi berkewajiban memenuhi kebutuhan end-user akan informasi cuaca terkini. Update perubahan keadaan cuaca signifikan juga harus dilaporkan guna menjaga keselamatan penerbangan. Dalam melaksanakan pelayanan informasi cuaca penerbangan Badan Meteorologi, Klimatologi, dan Geofisika (BMKG) memiliki target sasaran strategis yaitu pemerataan pemenuhan layanan informasi peringatan dini cuaca penerbangan yang memenuhi standar pelayanan minimal bidang meteorologi yaitu dengan akurasi 100\% [3]. Pada kegiatan pengamatan cuaca, BMKG masih menggunakan dua model pengamatan, yaitu pengamatan konvensional dan pengamatan otomatis. World Meteorological Organization (WMO) menargetkan untuk otomatisasi dengan target capaian tahun 2017 [4]. Hal ini mendorong BMKG untuk melakukan percepatan otomatisasi.

Dalam dunia penerbangan, ada tiga tahap utama dalam pelayanan, yaitu pre-flight service, in-flight service, dan post-flight service. Pre-flight service merupakan kegiatan penanganan penerbangan sebelum keberangkatan (di bandara asal/ origin station). In-flight service adalah kegiatan pelayanan selama penerbangan. Post-flight service adalah kegiatan penanganan penerbangan setelah kedatangan (di bandara tujuan/destination) [5]. Informasi cuaca dari kegiatan pengamatan cuaca permukaan dibutuhkan terlebih pada saat pre-flight dan post-flight, selama in-flight penerbang menggunakan panduan weather forecast yang disajikan oleh forecaster dalam flight document.

Pengamatan cuaca diperlukan untuk mengamati keadaan cuaca secara terus menerus dan berkesinambungan untuk mengetahui perubahan cuaca guna meminimalkan efek negatif dari perubahan yang ektrim [6]. Petugas yang melaksanakan pengamatan disebut pengamat (observer). Parameter yang diukur dalam pengamatan cuaca permukaan antara lain: angin, suhu, kelembaban, hujan, tekanan, penyinaran matahari, jarak pandang, dan awan. Pengamatan yang akurat terus menerus sangat bermanfaat bagi pengolahan data untuk prakiraan cuaca (weather forecast) dan menjadi bahan penelitian untuk fenomena perubahan iklim.

Terdapat dua jenis sistem pengamatan cuaca, yaitu: sistem pengamatan konvensional (conventional observing system) dan sistem pengamatan otomatis (automated observing system). Sistem pengamatan konvensional terdiri dari pengamat dan beberapa intrumentasi pengukur cuaca manual yang diletakkan di suatu taman pengamatan (observing park). Sedangkan sistem pengamatan cuaca otomatis mengunakan instrumentasi pengukur cuaca otomatis.

Automated Weather Observing System (AWOS) adalah instrumentasi pengamatan cuaca otomatis yang ditempatkan di bandara untuk mendapatkan data unsur-unsur cuaca secara otomatis [7]. Parameter cuaca diukur oleh sensor-sensor yang terpasang pada AWOS. Sensor-sensor tersebut antara lain digunakan untuk mengukur arah dan kecepatan angin, tekanan, suhu, kelembaban, hujan, awan, dan jarak pandang. Masing-masing sensor mengukur parameter cuaca, mengirimkannya hasil pengukuran ke Data Collections Platform (DCP) kemudian akan diproses oleh Central Data Processor (CDP) yang akan menyimpan 
dan menyajikan data pengamatan [8]. AWOS mengolah data menjadi informasi cuaca penerbangan dalam bentuk:

a. MetReport, yaitu: informasi cuaca rutin hanya untuk bandara setempat, tidak disebarkan keluar bandara, dan dipergunakan untuk keperluan tinggal landas dan pendaratan.

b. Special, yaitu: informasi cuaca khusus terpilih hanya untuk bandara setempat, tidak disebarkan keluar bandara, dilaporkan setiap saat bila ada perubahan unsur cuaca signifikan/ bermakna.

c. Metar: yaitu: nama sandi pelaporan cuaca rutin untuk penerbangan

d. Speci, yaitu nama sandi pelaporan cuaca khusus terpilih untuk penerbangan.

Prosedur pelayanan informasi cuaca menggunakan AWOS adalah pengamat melihat dan mengamati hasil unsur-unsur cuaca yang terekam dalam monitor AWOS kemudian melakukan validasi dengan membandingkan data hasil pengamatan dari AWOS dengan pengamatan konvensional [7].

Saat ini peralatan pengamatan cuaca otomatis belum terpasang di semua bandara. Pengamatan otomatis belum berjalan secara penuh dalam pelayanan cuaca penerbangan di BMKG. Untuk itu diperlukan suatu perencanaan enterprise yang mampu mendefinisikan kebutuhan bisnis dan arsitektur terkait data, aplikasi, dan teknologi yang dibutuhkan untuk mengimplementasikan otomatisasi dan modernisasi pelayanan pengamatan cuaca untuk penerbangan di lingkungan BMKG. Makalah ini mengusulkan sebuah blueprint implementasi pengamatan cuaca otomatis untuk pelayanan penerbangan di lingkungan BMKG yang dapat menjadi panduan bagi BMKG dalam mencapai visi terkait pelayanan cuaca penerbangan.

\section{Metodologi Penelitian}

Metode penelitian ini menggunakan kerangka Enterprise Architecture Planning (Steven Spewak) untuk menggambarkan sistem pengamatan cuaca konvensional yang sedang berjalan dan sistem pengamatan cuaca otomatis untuk masa mendatang. Enterprise Architecture (EA) merupakan suatu representasi dari struktur dan perilaku proses bisnis suatu perusahaan yang menggambarkan sistem yang yang sedang berjalan dan sistem di masa depan. EA meliputi: pemanfaatan teknologi informasi terkini, visi untuk pemanfaatan teknologi informasi masa depan, dan road map untuk evolusi teknologi informasi dari keadaan saat ini ke masa depan [9]. Beberapa model EA yang sering digunakan antara lain model Zachman Framework, Enterprise Architecture Planning (EAP), Togaf Adm, dan lain sebagainya.

EAP merupakan bagian dari zachman's framework, yaitu lapis kedua paling atas dari matrik zahman dimana tahapannya ditunjukkan pada gambar 1.

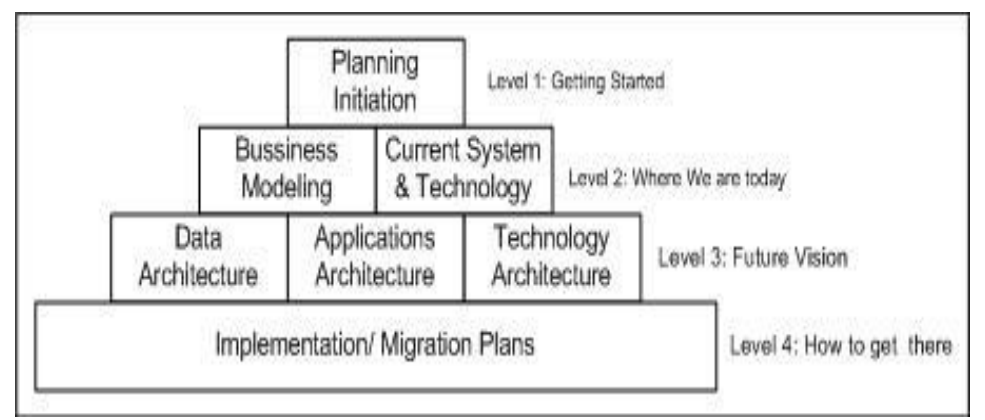

Gambar 1. Enterprise Architecture Planning (Steven Spewak) [10] 
EAP mendefinisikan kebutuhan bisnis dan arsitektur yang menjelaskan mengenai data, aplikasi, dan teknologi yang dibutuhkan untuk mendukung bisnis tersebut [11]. EAP terdiri dari empat tahapan, yaitu: inisiasi rencana, deskripsi keadaan saat ini, visi masa depan yang ingin dicapai, dan bagaimana mewujudkannya.

Pada Level pertama EAP menjelaskan bagaimana inisialisasi rencana otomatisasi yang dijalankan BMKG. Dalam menjalankan tugas dan fungsi terkait pelayanan cuaca penerbangan, BMKG memiliki visi untuk memberikan informasi yang akurat, tepat sasaran, tepat guna, cepat, lengkap, dan dapat dipertanggungjawabkan. Selain itu BMKG juga harus tanggap dalam menangkap dan merumuskan kebutuhan stakeholder akan informasi, serta mampu memberikan pelayanan sesuai dengan kebutuhan pengguna jasa. Dalam konteks pelayanan cuaca untuk penerbangan, output yang diharapkan adalah untuk menjaga keselamatan penerbangan. Level kedua EAP memberikan gambaran bagaimana bisnis model yang sedang terjadi di BMKG. Teknologi dan sistem yang digunakan untuk pengamatan cuaca penerbangan. Level ketiga EAP adalah skenario pandangan arsitektur di masa yang akan datang terkait data, aplikasi, dan teknologi yang akan digunakan. Sedangkan Level terakhir menjabarkan tentang bagaimana implementasi/ migrasi dari sistem yang lama (conventional) ke sistem otomatis yang baru (automated).

\section{Hasil dan Pembahasan}

Dalam upaya mewujudkan otomatisasi dan modernisasi pada proses diseminasi informasi cuaca terkini penerbangan, BMKG menggunakan pendekatan EAP untuk mengimplementasikan teknologi di masa yang akan datang. Proses pemodelan EAP dijalankan dengan tujuh langkah. Diawali dengan inisiasi rencana, pemodelan bisnis, tinjauan sistem dan teknologi yang digunakan saat ini, arsitektur data, arsitektur aplikasi, arsitektur teknologi, dan bagaimana proses implementasi/ migrasi.

\section{Planning Initiation}

BMKG dalam menjalankan tugas pelayanan informasi cuaca penerbangan mempunyai rencana otomatisasi dan modernisasi yang tertuang dalam Peraturan Kepala Badan Meteorologi, Klimatologi, dan Geofisika Nomor 5 Tahun 2014 Tentang Rencana Induk Badan Meteorologi, Klimatologi, dan Geofisika Tahun 2015 - 2045 [12]. Disebutkan bahwa BMKG telah melakukan berbagai upaya percepatan diseminasi informasi baik itu meteorologi, klimatologi, maupun geofisika. Salah satu bentuk otomatisasi yang akan dilakukan adalah mengganti sistem pengamatan konvensional menjadi pengamatan otomatis berbasis alat (instrumented) yang terintegrasi. Alat otomatis yang digunakan dalam pelayanan pengamatan cuaca terkini untuk penerbangan adalah AWOS. AWOS sebagai alat bantu BMKG dalam mewujudkan visi dalam pelayanan penerbangan yaitu mewujudkan keselamatan penerbangan.

\section{Business Modeling}

Bisnis model yang terjadi di BMKG pada pengamatan cuaca untuk penerbangan dalam penelitian ini fokus pada pengamatan cuaca penerbangan yang memiliki tujuan akhir untuk ikut menjaga keselamatan penerbangan. Proses pelayanan cuaca penerbangan dimodelkan dengan menggunakan Value Chain Model Analysis seperti ditunjukkan pada gambar 2. 


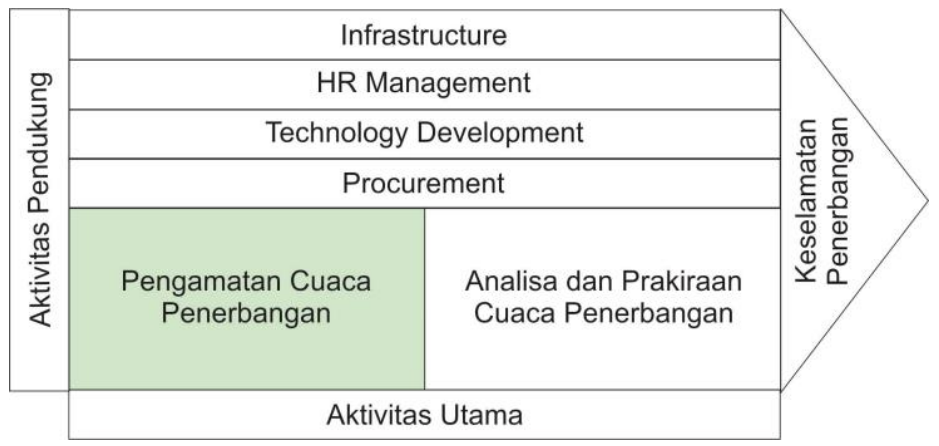

Gambar 2. Value Chain Model Analysis

BMKG melalui Stasiun Meteorologi memiliki dua aktivitas utama dalam pelayanannya, yaitu Pengamatan cuaca penerbangan serta analisa dan prakiraan cuaca penerbangan. Pengamatan cuaca penerbangan dilakukan oleh seorang pengamat baik menggunakan intrumentasi konvensional maupun AWOS. Alur data yang terjadi adalah parameter cuaca diamati oleh pengamat/AWOS, yang kemudian mengirimkan hasil pengamatan ke pengelola layanan navigasi penerbangan di bawah Perusahaan Umum Lembaga Penyelenggara Pelayanan Navigasi Penerbangan Indonesia (Perum. LPPNPI) melalui Aeronautical Fixed Telecommunication Network (AFTN) dan ke BMKG melalui jaringan Computer Message Switching System (CMSS), seperti ditunjukkan gambar 3.

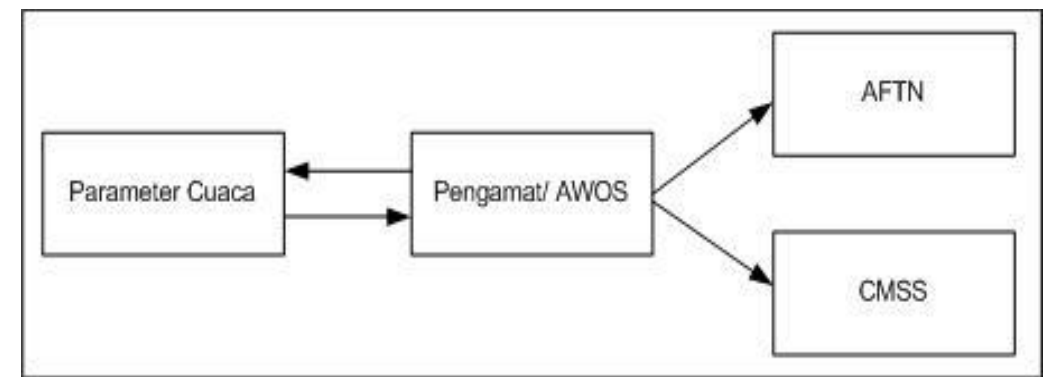

Gambar 3. Alur Pengamatan Cuaca

\section{Current System and Technology}

Dalam melakukan pelayanan informasi cuaca terkini untuk penerbangan, BMKG saat ini masih menggunakan dua jenis sistem pengamatan, yaitu: pengamatan konvensional dan otomatis. Pada pengamatan konvensional, pengamat mengamati cuaca menggunakan instrumentasi konvensional di taman pengamatan kemudian mencatat data pengukuran, dan mengirimkannya sebagai informasi cuaca terkini kepada LPPNPI dalam bentuk MetReport/ Special dan kepada BMKG dalam bentuk Metar/ Speci. Alur Sistem Pengamatan konvensional ditunjukkan pada gambar 4.

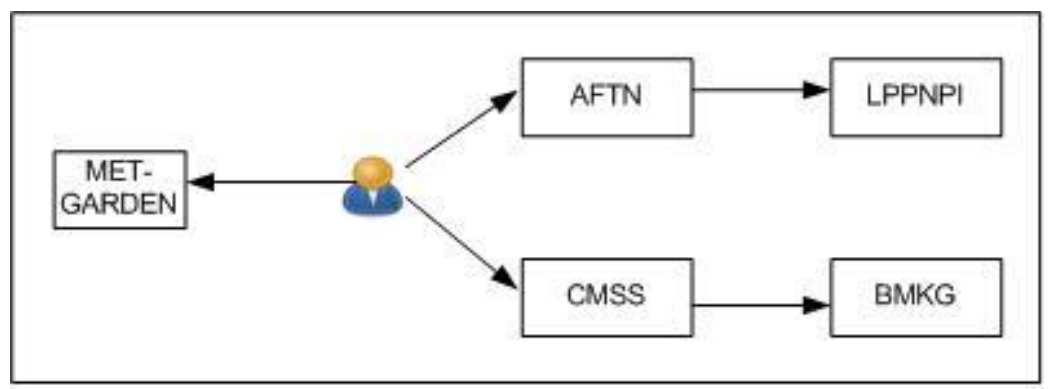

Gambar 4. Alur Sistem Pengamatan Konvensional 
Sistem Pengamatan Otomatis melibatkan pengamat dan intrumen pengukur cuaca otomatis/ AWOS. Display AWOS sebagai alat bantu pengamat untuk mengetahui nilai parameter unsur cuaca tanpa harus melakukan pengamatan ke taman pengamatan (observation park). Input data masih dilakukan secara manual oleh pengamat baik itu ke jaringan AFTN maupun ke jaringan CMSS. Sistem Pengamatan Otomatis yang digunakan BMKG menggunakan AWOS seperti ditunjukkan pada gambar 5.

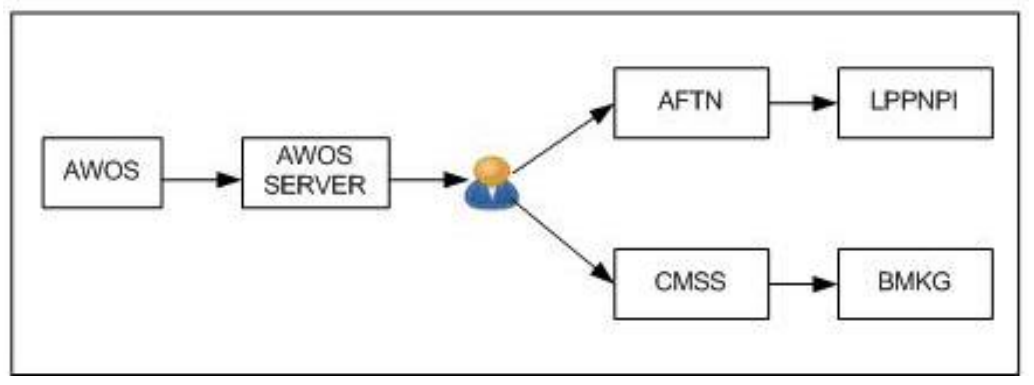

Gambar 5. Alur Sistem Pengamatan Otomatis

\section{Data Architecture}

Untuk melakukan otomatisasi pengamatan secara penuh, BMKG membutuhkan cetak biru (blueprint) arsitektur terkait data, aplikasi, dan teknologi yang akan digunakan.

Arsitektur data yang digunakan dalam perencanaan ini menggunakan pendekatan Two Layer Data Warehouse Architecture yang terdiri dari 4 lapisan. Model data warehouse ini memisahkan media penyimpanan antara sumber data dan data warehouse. Data Architecture ditunjukkan pada gambar 6.

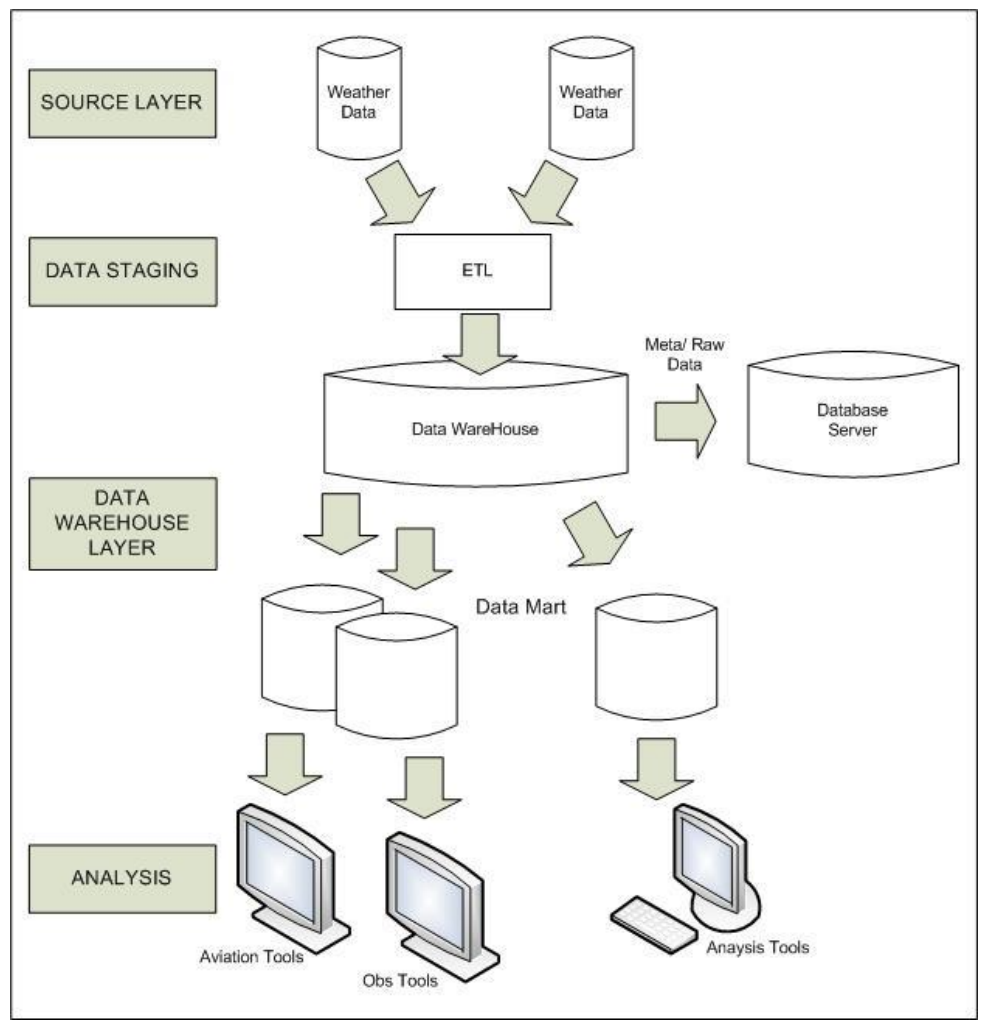

Gambar 6. Data Architecture 
Lapisan pertama adalah Source Layer. Lapisan ini merupakan sumber data yang berasal dari pengamatan parameter cuaca yang diperoleh dari sensor-sensor AWOS. Data yang diperoleh pada lapisan ini adalah data semua parameter cuaca seperti angin, suhu, kelembaban, hujan, tekanan, penyinaran matahari, jarak pandang, dan awan. Data masingmasing parameter diukur dalam frekuensi waktu tertentu yang sudah diatur sebelumnya, misalnya setiap 2 menit, 10 menit, 1 jam, atau 24 jam.

Lapisan kedua adalah Data Staging. Disinilah terjadi proses Extract, Transform, dan Load (ETL). Data parameter cuaca dari sensor diekstrak oleh DCP. Kemudian hasil ekstrak ini menjalani proses transformasi yang pada prinsipnya mengubah dalam bentuk standar. Proses Load adalah proses pengiriman data yang sudah menjalani transformasi ke gudang data yang berada dalam CDP.

Lapisan ketiga adalah Data Warehouse Layer. Informasi cuaca yang sudah tersimpan dalam gudang data dapat langsung digunakan atau dipisah-pisah dalam data mart sesuai peruntukannya. Pada pelayanan pengamatan cuaca untuk penerbangan, data mart yang dibuat, sesuai peruntukannya, adalah informasi yang berupa MetReport/ Special untuk AFTN dan Metar/ Speci untuk CMSS. Data mart yang lain yang dapat dibentuk adalah untuk keperluan analisis/ prakiraan cuaca terkait cuaca penerbangan dan iklim.

Lapisan keempat adalah Analysis Layer. Lapisan ini digunakan untuk melakukan pemanfaatan informasi dari data mart. Proses yang terjadi pada lapisan ini adalah penyandian data untuk pengiriman MetReport/ Special ke jaringan AFTN Bandara, pengiriman Metar/Speci pada jaringan CMSS, dan Analisa Prakiraan Cuaca ke jaringan lokal.

\section{Application Architecture}

Arsitektur aplikasi yang baik untuk digunakan dalam model pelayanan informasi pengamatan cuaca penerbangan ini adalah berbasis client server (Two-Tier Application). Server sebagai penyedia data dan client adalah pengguna data (end-user). Service bisnis yang terjadi dikelola di sisi server (server-centric). Hal ini akan memudahkan ketika terdapat perubahan service bisnis. Perubahan lebih cepat karena cukup hanya dilakukan di sisi server saja. Gambar 7 menunjukkan model Server Centric.

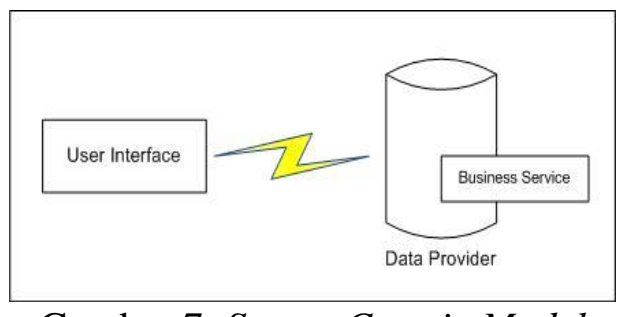

Gambar 7. Server Centric Model

Aristektur aplikasi perlu dipetakan untuk mengintegrasikan seluruh kebutuhan bisnis organisasi akan informasi. Kebutuhan bisnis dalam konteks ini adalah kebutuhan informasi cuaca penerbangan terkini yang didapat dari hasil pengamatan parameter cuaca. Arsitektur aplikasi pada pelayanan pengamatan cuaca penerbangan ditunjukkan pada gambar 8 . 


\begin{tabular}{|c|c|c|c|c|c|c|c|}
\hline \multicolumn{2}{|c|}{$\begin{array}{l}\text { Broadcast Metar } \\
\text { Application }\end{array}$} & \multicolumn{2}{|c|}{$\begin{array}{l}\text { Broadcast MetReport } \\
\text { Application }\end{array}$} & \multicolumn{2}{|c|}{$\begin{array}{l}\text { AWOS Display } \\
\text { Application }\end{array}$} & \multicolumn{2}{|c|}{$\begin{array}{l}\text { Forecast Analysis } \\
\text { Application }\end{array}$} \\
\hline \multicolumn{4}{|c|}{ Observer Validations } & \multirow{2}{*}{\multicolumn{2}{|c|}{ Display Data Mart }} & \multirow{2}{*}{\multicolumn{2}{|c|}{$\begin{array}{l}\text { Forecast Analysis } \\
\text { Data Mart }\end{array}$}} \\
\hline Metar & a Mart & MetRep & Data Mart & & & & \\
\hline \multicolumn{8}{|c|}{ DATA WAREHOUSE } \\
\hline 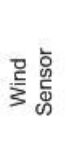 & 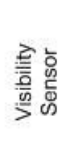 & 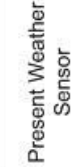 & 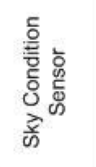 & 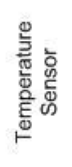 & 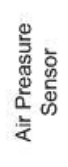 & 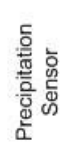 & $\begin{array}{l}\text { D. } \\
\text { 喜 } \\
\text { 总 } \\
\text { 兽心 }\end{array}$ \\
\hline
\end{tabular}

Gambar 8. Aplication Architecture

Sensor-sensor merupakan sumber data dari data warehouse. Data warehouse menyediakan data mart untuk masing-masing aplikasi sesuai dengan kebutuhannya. Khusus untuk aplikasiaplikasi dengan tipe broadcast messages, diperlukan proses validasi, untuk memastikan tidak terjadi kesalahan pada pengukuran sensor.

\section{Technology Architecture}

Arsitektur teknologi adalah skenario teknologi yang digunakan untuk mengimplementasikan otomatisasi pelayanan informasi cuaca terkini untuk penerbangan di lingkungan BMKG. Arsitektur teknologi mendeskripsikan kebutuhan infrastruktur, termasuk jaringan, yang dibutuhkan dalam mewujudkan visi yang ingin dicapai. Skenario arsitektur teknologi ditunjukkan pada gambar 9 .

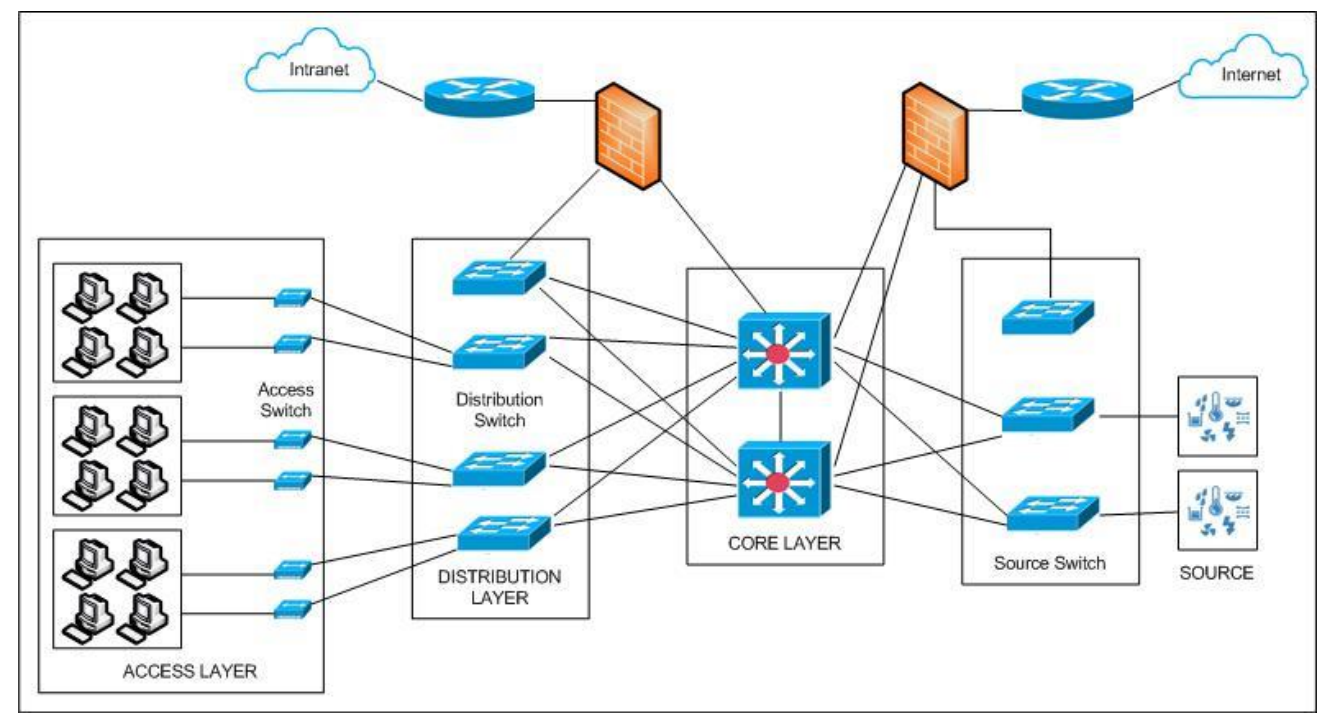

Gambar 9. Technology Architecture

Source Layer terdiri dari sensor-sensor pengukur parameter cuaca yang akan memberikan nilai pengamatan pada waktu tertentu yang akan dikumpulkan oleh DCP, diekstrak, dan dikirimkan ke CDP pada Core Layer. Pada lapisan inilah data-warehouse dan data-mart disimpan yang kemudian akan didistribusikan melalui Distribution Layer untuk selanjutnya dibagi sesuai kebutuhan akses end-user pada Access Layer.

Konektivitas dari sumber data (source) hingga ke core layer dirancang menggunakan saluran fiber optic. Fiber optik merupakan media transfer data paling efektif, memiliki tingkat 
loss data dan gangguan yang rendah, serta bandwith yang tinggi untuk menjaga keberlangsungan data yang berkesinambungan secara realtime. Semua lapisan dalam jaringan yaitu core layer, distribution layer dan access layer menggunakan jalur ganda pada switch yang dipakai, sehingga ketika salah satu perangkat switch rusak/ off, otomatis akan melalui switch yang lain agar tetap terhubung. Begitu juga untuk koneksi ke luar (internet) menggunakan lebih dari satu provider sehingga konektivitas tetap terjaga guna mendukung proses data sharing layanan penerbangan.

\section{Implementation/ Migration Plans}

Proses implementasi pelayanan pengamatan cuaca otomatis di BMKG diawali dengan pengadaan AWOS untuk stasiun-stasiun yang masih menggunakan sistem pengamatan konvensional. Sedangkan untuk stasiun yang sudah menggunakan AWOS supaya dapat merealisasikan otomastisasi penuh pada kegiatan pengamatan, sehingga mengurangi campur tangan manusia dalam proses ini. Pengamat dibutuhkan hanya untuk melakukan validasi ketika ada sensor otomatis yang tidak bekerja dengan semestinya. Peralatan pengukur cuaca konvensional dialihfungsikan menjadi alat bantu validator dari informasi AWOS.

Proses otomatisasi ini tidak dapat serta merta dilakukan dengan semata-mata menggantikan sistem pengamatan manual menjadi otomatis begitu saja. Di masing-masing stasiun perlu dilakukan dual observation (pengamatan bersama otomatis dan manual) secara overlapping selama 2 hingga 3 tahun berturut-turut untuk menentukan dan mengidentifikasi faktor-faktor koreksi yang harus dicakup dalam data analisis. Pemeliharaan AWOS yang berkesinambungan dan kalibrasi yang terjadwal menjadi poin penting yang harus diperhatikan untuk menjaga kualitas data pengamatan.

BMKG juga perlu melakukan integrasi semua peralatan AWOS yang sudah terpasang dengan memperhatikan prinsip-prinsip interoperabilitas agar tercipta standar-standar konektivitas untuk memudahkan proses pengembangan sistem di masa yang akan datang. Teknologi Cloud menjadi referensi untuk dapat mengkoneksikan data AWOS dengan data dari instrumentasi otomatis lainnya seperti Automatic Weather Stations (AWS), Agroclimate Auotomatic Weather Stations (AAWS), maupun Automatic Rain Gauge (ARG) sehingga tercipta integrasi yang baik di lingkungan $B M K G$ maupun dengan instansi terkait lainnya.

\section{Kesimpulan}

Enterprise Architecture Planning (EAP) dapat digunakan untuk membuat cetak biru (blueprint) implementasi pengamatan cuaca untuk pelayanan penerbangan di lingkungan BMKG. EAP mampu mendefinisikan kebutuhan bisnis dan arsitektur terkait data, aplikasi, dan teknologi yang dibutuhkan untuk mengimplementasikan otomatisasi. Overlapping pada proses migrasi diharapkan mampu menjadi bahan evaluasi dalam implementasi otomatisasi.

\section{Daftar Pustaka}

[1] Poerwanto, E., \& Mauidzoh, U. (2016). Analisis Kecelakaan Penerbangan Di Indonesia Untuk Peningkatan Keselamatan Penerbangan. Angkasa: Jurnal Ilmiah Bidang Teknologi, 8(2), 9-26. 
[2] Kementrian Perhubungan, Peraturan Menteri Perhubungan Republik Indonesia No. PM 9 Tahun 2015 tentang Peraturan Keselamatan Penerbangan Sipil Bagian 174 (Civil Aviation Safety Regulations Part 174) Tentang Pelayanan Informasi Meteorologi Penerbangan (Aeronautical Meteorological I. Jakarta, 2015.

[3] BMKG, Peraturan Kepala Badan Meteorologi, Klimatologi, dan Geofisika Republik Indonesia No.15 Tahun 2017. Jakarta, 2017.

[4] BMKG, Peraturan Kepala BMKG No.009 Tahun 2015 Tentang Rencana Strategis Badan Meteorologi Klimatologi dan Geofisika Tahun 2015-2019. Jakarta, 2015.

[5] Poerwanto, E., \& Gunawan, G. (2015). Analisis Beban Kerja Mental Pekerja Bagian Ground H Andling Bandara Adisutjipto untuk Mendukung Keselamatan Penerbangan. Angkasa: Jurnal Ilmiah Bidang Teknologi, 7(2), 115-126.

[6] E. Buyukbas, L. Yalcin, Z. T. Dag, and S. Karatas, "Instruments and Observing Methods," Alanya, Turkey, 2005.

[7] BMKG, SOP No.001 Tahun 2017 Tentang Pelayanan Cuaca Untuk Informasi Cuaca Penerbangan Bila Sarana AWOS Terjadi Malfungsi. Jakarta, 2017.

[8] A. W. Inc., Automated Weather Observing System (AWOS) 3000 User's Manual, Rev.G. Sacramento, CA, USA: All Weather Inc., 2017.

[9] Bente, S., Bombosch, U., \& Langade, S. (2012). Collaborative enterprise architecture: Enriching ea with lean. Agile, and Enterprise 2.0 practices, Eds. Elsevier.

[10] Spewak, S. H., \& Hill, S. C. (1993). Enterprise architecture planning: developing a blueprint for data, applications and technology. QED Information Sciences, Inc..

[11] S. Kasus, B. Pendidikan, D. Kab, and L. Tengah, "Perancangan arsitektur sistem informasi menggunakan enterprise arsitecture planning," vol. 13, no. 1, pp. 41-51, 2013.

[12] P. B. No.5, Rencana Induk Badan Meteorologi, Klimatologi, dan Geofisika Tahun 2015-2045. Jakarta, 2014. 